\title{
Development of real-time PCR assays for discrimination and quantification of two Perkinsus spp. in the Manila clam Ruditapes philippinarum
}

\author{
Kousuke Umeda, Tomoyoshi Yoshinaga* \\ Department of Aquatic Bioscience, Graduate School of Agricultural and Life Sciences, The University of Tokyo, \\ Tokyo 113-8657, Japan
}

\begin{abstract}
The Manila clam Ruditapes philippinarum is infected with 2 Perkinsus species, Perkinsus olseni and P. honshuensis, in Japan. The latter was described as a new species in Mie Prefecture, Japan, in 2006. Ray's Fluid Thioglycollate Medium (RFTM) assay has been most commonly used to quantify Perkinsus infection. However, this assay cannot discriminate between species that resemble one another morphologically. We developed real-time PCR assays for the specific quantification of $P$. olseni and $P$. honshuensis. DNA was extracted using Chelex resin. Cultured $P$. olseni and $P$. honshuensis cells were counted and spiked into uninfected clam gill tissue prior to DNA extraction to generate standard curves, which allowed quantification based on the PCR cycle threshold values. We compared the RFTM assay with both real-time PCR assays by quantifying Perkinsus spp. in gill tissue samples from the same individual clams obtained from various localities in Japan. Infection intensities estimated by both assays were significantly correlated $\left(\mathrm{r}^{2}=0.70\right)$. Our results suggest that the prevalence and infection intensity of $P$. honshuensis are much lower than for $P$. olseni in Manila clams.
\end{abstract}

KEY WORDS: Perkinsus olseni - Perkinsus honshuensis - qPCR · Ruditapes philippinarum • Manila clam $\cdot$ RFTM

Resale or republication not permitted without written consent of the publisher

\section{INTRODUCTION}

In Japan, the annual catch of the Manila clam Ruditapes philippinarum was between 100000 and 160000 metric tons from the 1960 s to early 1980s, peaking at 160000 tons in 1983. Since then, the annual catch has decreased dramatically and has remained below 40000 tons in the last decade (Annual Statistics of Fishery and Fish Culture, Ministry of Agriculture, Forestry and Fisheries, Japan). Matsukawa et al. (2008) suggested that the decline was caused by overfishing, degeneration of sediments, mass depletion of larvae, and/or feeding damage by predatory animals. However, the exact cause(s) remain unclear. We hypothesized that infection with the protozoan parasites Perkinsus olseni and/or $P$. honshuensis has played an important role in the depletion of Manila clam populations.

The genus Perkinsus includes protozoan endoparasites that infect marine mollusks and are likely closely related to dinoflagellates (Saldarriaga et al. 2003). Perkinisus marinus was at least partly responsible for mass mortalities and stock depletion of the eastern oyster Crassostrea virginica on the east coast of the United States (Andrews \& Hewatt 1957, Ewart \& Ford 1993). A second species, P. olseni, was also implicated in the mass mortalities experienced by abalones Haliotis spp. in Australia and the gloved 
carpet shell clam Ruditapes decussatus in Spain and Portugal (Ruano \& Cachola 1986, Azevedo 1989, Goggin \& Lester 1995). In East Asia, several researchers have suggested that infection with $P$. olseni caused mass mortalities and stock depletion of Manila clams in some regions of Korea and Japan (Hamaguchi et al. 1998, Park \& Choi 2001). Because of their potential risk to the health of aquatic mollusks, the 2 Perkinsus species are listed pathogens requiring notification to the World Organization for Animal Health (OIE) (World Organization for Animal Health 2010).

Until recently, it was thought that the Manila clam was infected only with Perkinsus olseni in Japan. However, Dungan \& Reece (2006) described P. honshuensis, a new species, in Manila clams collected from Mie Prefecture, Japan. P. olseni is distributed throughout the tropical Pacific Ocean, Australia, the North Island of New Zealand, Vietnam, Korea, Japan, China, Portugal, Spain, France, Italy, and Uruguay. $P$. olseni also infects a wide range of hosts, including clams, oysters, pearl oysters, abalones, and possibly other bivalve and gastropod species (Azevedo 1989, Goggin \& Lester 1995, Hamaguchi et al. 1998, Park \& Choi 2001, Casas et al. 2002, Villalba et al. 2004, Cremonte et al. 2005). Perkinsus infections have been reported in Manila clams throughout Japan, except for regions of northern and eastern Hokkaido (Hamaguchi et al. 2002, Nishihara 2010). However, previous reports of Perkinsus infection in Manila clams from Japan have not distinguished between the 2 species. Thus, their relative distribution is largely unknown and the impact of each species on their host has not been sufficiently evaluated particularly in field surveys.

Perkinsus spp. are most commonly detected and quantified using Ray's Fluid Thioglycollate Medium (RFTM) assay (Ray 1952, 1966). However, this method cannot distinguish between Perkinsus species because of their morphological similarity. In addition, the RFTM assay requires a long culture period (>4 d). Recently, Takahashi et al. (2009) developed a PCR-RFLP method to distinguish $P$. olseni and $P$. honshuensis, demonstrating that both species are present in western Japan. Unfortunately, it is not possible to quantify the intensity of infection using PCR-RFLP.

We aimed to develop real-time PCR assays for the discrimination and quantification of Perkinsus olseni and $P$. honshuensis to investigate their distribution in wild Manila clams. We compared the results obtained using real-time PCR and RFTM in naturally infected clams.

\section{MATERIALS AND METHODS}

\section{Clams}

We purchased uninfected Manila clams from the Akkeshi fisheries cooperative association. The clams were collected from the tidal flat at Akkeshi, Hokkaido, Japan, an area that is free of Perkinsus spp. We purchased naturally infected Manila clams that were collected in Aichi Prefecture from a local retailer in Tokyo. In addition, we collected naturally infected Manila clams from 4 locations: Ariake Basin, Kumamoto Prefecture; Lake Hamana, Shizuoka Prefecture; an unnamed bay, Mie Prefecture, where $P$. honshuensis was first described; and the Marine Park in Kanagawa Prefecture.

\section{Parasites}

We purchased trophozoites of Perkinsus olseni (ATCC PRA-181) and P. honshuensis (ATCC PRA177) from the American Type Culture Collection and cultured them in Perkinsus broth medium (PBM) (ATCC medium 1886) as follows. We added $1 \mathrm{ml}$ of old culture to $10 \mathrm{ml}$ fresh medium at 2 to $3 \mathrm{wk}$ intervals, and incubated the medium at $25^{\circ} \mathrm{C}$. Cultures of $P$. olseni and $P$. honshuensis were filtered through $10 \mu \mathrm{m}$ nylon mesh to remove aggregated trophozoites. The filtrate was then centrifuged at $275 \times g$ for $5 \mathrm{~min}$ and the pelleted cells were resuspended in $3 \mathrm{ml}$ modified phosphate buffered saline (MPBS: $0.2 \mathrm{~g}$ $\mathrm{KCl}, 0.2 \mathrm{~g} \mathrm{KH}_{2} \mathrm{PO}_{4}, 2.9 \mathrm{~g} \mathrm{Na}_{2} \mathrm{HPO}_{4} \cdot 12 \mathrm{H}_{2} \mathrm{O}, 20.5 \mathrm{~g}$ $\mathrm{NaCl}, 1 \mathrm{l}$ distilled water [DW], $720 \mathrm{mOsm}$ ), which was made isotonic with $\mathrm{PBM}$ by increasing $\mathrm{NaCl}$ in Dulbecco's phosphate buffered saline. Stock solutions of trophozoites of Perkinsus species were prepared as described above throughout this study. We quantified the cell density of the resuspended cells using a hemocytometer. All counts were conducted in triplicate and the mean value was used for analysis.

Ethanol-fixed trophozoites of a range of Perkinsus species (Table 1) were provided by Chris Dungan (Cooperative Oxford Laboratory, Maryland Department of Natural Resources) for use in the primer specificity test.

\section{Real-time PCR}

We developed 2 real-time quantitative PCR protocols for the discrimination and quantification of Perkinsus olseni and P. honshuensis genomic DNA 
Table 1. Isolates of Perkinsus spp. used to test the specificity of the primer sets. ATCC: American Type Culture Collection; C: clonal strain; P: polyclonal strain

\begin{tabular}{|c|c|c|c|c|c|c|}
\hline Isolate identity & Isolate code & ATCC no. & Clonality & Source host & Source state & Source country \\
\hline \multirow[t]{6}{*}{ Perkinsus olseni } & PaG3F & PRA-31 & $\mathrm{P}$ & Ruditapes decussatus & Galicia & Spain \\
\hline & NZMSAs-5/C9 & PRA-205 & $\mathrm{C}$ & Austrovenus stutchburyi & North Island & New Zealand \\
\hline & Mie-4g/F6 & PRA-179 & $\mathrm{C}$ & Ruditapes philippinarum & Mie & Japan \\
\hline & Mie-13v/H8 & PRA-183 & $\mathrm{C}$ & Ruditapes philippinarum & Mie & Japan \\
\hline & Mie-5mg & PRA-180 & $\mathrm{P}$ & Ruditapes philippinarum & Mie & Japan \\
\hline & Mie-5mg/F8 & PRA-181 & $\mathrm{C}$ & Ruditapes philippinarum & Mie & Japan \\
\hline \multirow[t]{2}{*}{ Perkinsus honshuensis } & Mie-3g & PRA-176 & $\mathrm{P}$ & Ruditapes philippinarum & Mie & Japan \\
\hline & Mie-3g/H8 & PRA-177 & $\mathrm{C}$ & Ruditapes philippinarum & Mie & Japan \\
\hline Perkinsus marinus & CRTW-3he & 50439 & $\mathrm{P}$ & Crassostrea virginica & Maryland & USA \\
\hline Perkinsus chesapeaki & CHBRMa-14 & PRA-65 & $\mathrm{P}$ & Mya arenaria & Maryland & USA \\
\hline
\end{tabular}

targeting the internal transcribed spacer (ITS) region. The primer sets (Table 2) were designed using BioEdit (Ibis Biosciences) based on the known sequences of the genus Perkinsus registered in GenBank (www.ncbi.nlm.nih.gov/genbank/). Real-time PCR assays were performed in 8-strip tubes using a MiniOpticon real-time PCR detection system (BioRad Laboratories Japan). Each tube (20 $\mu$ l) contained $10 \mu \mathrm{l}$ of SsoFast EvaGreen Supermix (Bio-Rad Laboratories Japan), $0.1 \mu \mathrm{l}$ of each primer $(100 \mu \mathrm{M}), 1 \mu \mathrm{l}$ of template DNA and $8.8 \mu \mathrm{l}$ of ultrapure water. The thermal cycling conditions were: 1 cycle of polymerase activation at $98^{\circ} \mathrm{C}$ for $2 \mathrm{~min} ; 40$ cycles of amplification at $98^{\circ} \mathrm{C}$ for $2 \mathrm{~s}$ and $60^{\circ} \mathrm{C}$ for $5 \mathrm{~s} ; 1$ cycle of annealing at $60^{\circ} \mathrm{C}$ for $5 \mathrm{~min}_{\text {; }}$ and melting curve analysis at 60 to $98^{\circ} \mathrm{C}$ in which the temperature was increased by $0.1^{\circ} \mathrm{C}$ every $5 \mathrm{~s}$ to determine the purity of PCR products. We included negative controls in all PCR runs (ultrapure water only and extract of uninfected clam only) to rule out DNA contamination.

\section{Primer specificity}

Genomic DNA was extracted from 10 isolates of Perkinsus spp. (Table 1) using a 10\% (w/w) Chelex (Bio-Rad Laboratories Japan) resin solution (Barber \& Erdmann 2000, De Faveri et al. 2009). Briefly, Chelex

Table 2. Primer sets used in this study for Perkinsus spp.

\begin{tabular}{|c|c|c|}
\hline $\begin{array}{l}\text { Target } \\
\text { species }\end{array}$ & $\begin{array}{l}\text { Primer } \\
\text { name }\end{array}$ & Oligonucleotide sequence $\left(5^{\prime}-3^{\prime}\right)$ \\
\hline P. olseni & $\begin{array}{l}\text { OF } \\
\text { OR }\end{array}$ & $\begin{array}{l}\text { Forward: CTT AAC GGG CCG TGT TA } \\
\text { Reverse: CAT AAC GAA CTA TCT CCG AAG }\end{array}$ \\
\hline P. honshuensis & $\begin{array}{l}\mathrm{HF} \\
\mathrm{HR}\end{array}$ & $\begin{array}{l}\text { Forward: CTG CCT GGC AGG TGA T } \\
\text { Reverse: CGA ATT GGC TCA ATA AAT TG }\end{array}$ \\
\hline
\end{tabular}

solution was prepared by suspending molecular biology grade Chelex 100 resin (200-400 dry mesh, 75-150 $\mu \mathrm{m}$ wet beads; Biorad-Laboratories Japan) in ultrapure water. A small volume $(<20 \mu \mathrm{l})$ of ethanolfixed parasite cell pellet was transferred into a $1.5 \mathrm{ml}$ microtube. We then added $1 \mathrm{ml}$ of $10 \%$ Chelex solution to each tube and incubated the mixture at $95^{\circ} \mathrm{C}$ in a dry bath for $45 \mathrm{~min}$. The concentrations of all DNA extracts were determined using a spectrophotometer. To test the specificity of the primer sets designed for $P$. olseni and $P$. honshuensis, we performed real-time PCR on the extracted DNA. The amount of template DNA was between 100 and $200 \mathrm{ng}$ per reaction.

\section{Effect of clam tissue on PCR amplification}

To test the influence of clam tissue on PCR amplification, we compared PCR amplification between 2 groups of samples. We prepared a serial dilution series of Perkinsus trophozoite cultures $\left(5.0 \times 10^{6}\right.$ to 5.0 cells per $\mathrm{ml}$ ). The first group consisted of DNA samples extracted from a $300 \mu \mathrm{l}$ trophozoite suspension. The second group consisted of DNA samples extracted from uninfected clam gill tissues inoculated with the trophozoite suspension. The gills were excised from uninfected clams collected at Akkeshi and minced with clean scissors. Thirty milligrams (wet mass) of the minced gill tissue was transferred into a $1.5 \mathrm{ml}$ microtube, to which $300 \mu \mathrm{l}$ of the serially diluted trophozoite suspension was added. The mixture was then centrifuged at $800 \times g$ for $5 \mathrm{~min}$ to obtain gill tissue spiked with trophozoites. The tissues were then extracted with Chelex resin as 
described above. We carried out the real-time PCR runs using the DNA solutions as template. The experiment was repeated for both species.

\section{Comparison of DNA extraction methods}

We spiked uninfected clam gill tissues with serially diluted trophozoites of each Perkinsus species $(4.0 \times$ $10^{7}$ to $4.0 \times 10^{2}$ cells g ${ }^{-1}$ wet tissue mass). DNA was then immediately extracted from the tissues using one of 3 methods: QIAamp DNA Mini Kit (Qiagen), QIAamp DNA Stool Mini Kit (Qiagen), or Chelex resin. We extracted DNA from 25 and $50 \mathrm{mg}$ of the spiked gill tissues using the QIAamp DNA Mini Kit (following the protocol for tissue extraction) and the QIAamp DNA Stool Mini Kit (following the protocol for isolation of DNA from stools for pathogen detection), respectively. The final solution volume was $200 \mu \mathrm{l}$ for both methods. We also extracted DNA from $30 \mathrm{mg}$ of spiked gill tissue using a $10 \%$ Chelex resin solution as described above. We carried out the realtime PCR runs using the DNA solutions as a template.

\section{Preparation of standard samples}

We prepared standard samples for real-time PCR by spiking the gill tissue of uninfected clams with cultured trophozoites. Serial dilutions of both species were prepared over a range of 7 orders of magnitude $\left(5.0 \times 10^{6}\right.$ to 5.0 cells $\left.\mathrm{ml}^{-1}\right)$. We then added $300 \mu \mathrm{l}$ of each dilution to a $1.5 \mathrm{ml}$ tube containing clam gill tissue $(30 \mathrm{mg})$. The tubes were centrifuged at $800 \times g$ for $5 \mathrm{~min}$, after which the supernatant was removed. DNA was extracted from these samples with a $10 \%$ Chelex resin solution as described above. We prepared 3 serial dilutions from 3 concentrated trophozoite samples for each Perkinsus species and used real-time PCR to generate a standard curve. We performed linear regression analysis to determine the relationship between Perkinsus spp. cell density and threshold cycle $\left(C_{\mathrm{T}}\right)$ values generated by the realtime PCR assay.

We evaluated whether real-time PCR can be used to accurately quantify the number of Perkinsus honshuensis cells when the level of infection is significantly lower than that of $P$. olseni. We performed real-time PCR on samples that were prepared as follows: Four sets of $30 \mathrm{mg}$ gill tissues (wet mass) were removed from uninfected Manila clams, minced with sterile scissors, and transferred to a $1.5 \mathrm{ml}$ microtube. We then added $300 \mu$ l of serially diluted P. honshuen- sis trophozoites $\left(4.0 \times 10^{6}\right.$ to 4.0 cells per $\left.\mathrm{ml}\right)$ to each tissue sample. In addition, we added $300 \mu$ of $P$. olseni trophozoite suspensions $\left(1.0 \times 10^{7}\right.$ cells per ml $)$ to 2 of the 4 tissue samples. The mixture was briefly vortexed and centrifuged at $800 \times g$ for $5 \mathrm{~min}$. The supernatant was discarded and DNA was immediately extracted with Chelex resin as described above.

\section{Comparison of tissue preservation method}

To evaluate the effect of the method of tissue preservation prior to DNA extraction, we prepared standard curves using spiked gill tissue samples that were processed using one of 3 methods. Spiked standard samples prepared in the same way as described above were subjected to DNA extraction immediately after preparation, frozen at $-20^{\circ} \mathrm{C}$ overnight, or fixed in $500 \mu \mathrm{l}$ of $95 \%$ ethanol at $-20^{\circ} \mathrm{C}$ overnight before DNA extraction. The ethanol-fixed samples were centrifuged $(800 \times g, 5 \mathrm{~min})$ to remove ethanol before DNA extraction. DNA extraction was performed with Chelex resin as described above. We prepared 2 serial dilutions generated from 2 different trophozoite stocks and subjected them to real-time PCR to obtain the standard curve.

\section{Comparison of tissue types}

We spiked minced gill tissue or minced whole soft body with 10 -fold serially diluted trophozoites of the 2 Perkinsus species. The spiked samples were subjected to DNA extraction with Chelex resin followed by real-time PCR. We prepared 2 serial dilutions generated from 2 different trophozoite stocks. The serial dilutions were then subjected to real-time PCR to obtain standard curves.

\section{Comparison of the real-time PCR and RFTM assays}

We quantified the trophozoites of the 2 Perkinsus species in naturally infected Manila clams using both real-time PCR and the RFTM assay. Both sides of the gills were excised from Manila clams $(n=16$ from Aichi Prefecture, $\mathrm{n}=22$ from the Ariake Basin, $\mathrm{n}=18$ from Lake Hamana, $\mathrm{n}=16$ from the location at which $P$. honshuensis were first described in Mie Prefecture, and $n=20$ from the Marine Park). The whole gill leaves from one side of the body were weighed and processed immediately using RFTM following the method of Ray $(1952,1966)$, as modified by Choi 
et al. (1989). In brief, gill tissue samples were placed in screw-capped test tubes containing $5 \mathrm{ml}$ of RFTM (14.9 $\mathrm{g}$ fluid thioglycollate medium, $10 \mathrm{~g} \mathrm{NaCl}, 500 \mathrm{ml}$ DW). We added 500 units $\mathrm{ml}^{-1}$ penicillin $\mathrm{G}$ potassium and $500 \mu \mathrm{g} \mathrm{ml}^{-1}$ streptomycin sulfate to inhibit bacterial growth. The samples were then incubated at $25^{\circ} \mathrm{C}$ in the dark for 4 to $7 \mathrm{~d}$; the length of the incubation period (within this range) had little effect in our preliminary study. Following incubation, the media was centrifuged at $275 \times g$ for $5 \mathrm{~min}$ and the resulting pellets were lysed in $10 \mathrm{ml}$ of $2 \mathrm{M} \mathrm{NaOH}$ at $60^{\circ} \mathrm{C}$ until the tissue was fully lysed. The lysates were washed twice in DW. After the final centrifugation step, the pellets were resuspended in $1 \mathrm{ml}$ DW. The suspensions were 10 -fold serially diluted in a 96-well microplate. Hypnospores in the well were stained with a drop of Lugol's iodine solution and counted under an inverted microscope.

A sample of the gill tissue from the opposing side was transferred into a $1.5 \mathrm{ml}$ microtube, homogenized with a Nippi Bio-Masher II, and weighed (<40 mg). Total DNA was extracted from the homogenates with Chelex resin and subjected to both real-time PCR assays for quantification of the 2 Perkinsus species. A standard curve was generated using Manila clam gill tissues spiked with 10-fold serially diluted trophozoites of the 2 Perkinsus species. We compared the estimates of infection intensity from the RFTM assay and both real-time PCR assays using linear regression analysis and a BlandAltman plot.

\section{RESULTS}

\section{Primer specificity}

Only the target species exhibited a positive reaction during real-time PCR, with the exception that the primer sets designed for Perkinsus olseni and $P$. honshuensis both yielded a positive reaction to DNA extracted from the $P$. honshuensis strain (PRA 176) (Table 3). PRA 176 is a polyclonal strain isolated from a clam that was collected from the site in Mie Prefecture, where both species are present (Dungan \& Reece 2006). The $C_{\mathrm{T}}$ values for this strain were 15.7 and 26.7 for the primer sets designed for $P$. honshuensis and P. olseni, respectively.

\section{Effect of clam tissue on PCR amplification}

DNA samples extracted from clam gill tissues spiked with trophozoites had higher $C_{\mathrm{T}}$ values by 3 to 5 units than those extracted from trophozoites alone (Fig. 1).

\section{DNA extraction methods}

We did not detect an amplification signal following real-time PCR on Perkinsus honshuensis DNA extracted with the QIAamp DNA Mini kit. DNA of the 2 Perkinsus species extracted with the QIAamp DNA stool kit yielded a little higher $C_{\mathrm{T}}$ values than for DNA extracted with Chelex resin (Fig. 2). The $C_{\mathrm{T}}$ values for DNA extracted with Chelex resin were the lowest among the 3 extraction methods for both Perkinsus species.

\section{Preparation of standard samples}

The $C_{\mathrm{T}}$ values obtained from the standard samples exhibited a clear linear correlation with trophozoite density in both species $\left(\mathrm{r}^{2}>0.96\right.$; Fig. 3$)$. We occasionally observed non-specific amplification of DNA, even in the negative controls after 40 cycles. DNA amplification was detected within the range of $1.5 \times$ $10^{6}$ to $1.5 \times 10^{0.5}$ cells for both Perkinsus olseni and $P$. honshuensis per $30 \mathrm{mg}$ of wet gill tissue. This equates to $5.0 \times 10^{7}$ to $5.0 \times 10^{1.5}$ trophozoites $\mathrm{g}^{-1}$ wet gill tissue. We observed very little variation in the ranges between PCR runs.

The $C_{\mathrm{T}}$ values for Perkinsus honshuensis DNA were very similar between corresponding samples despite the presence of $P$. olseni trophozoites (Fig. 4). 


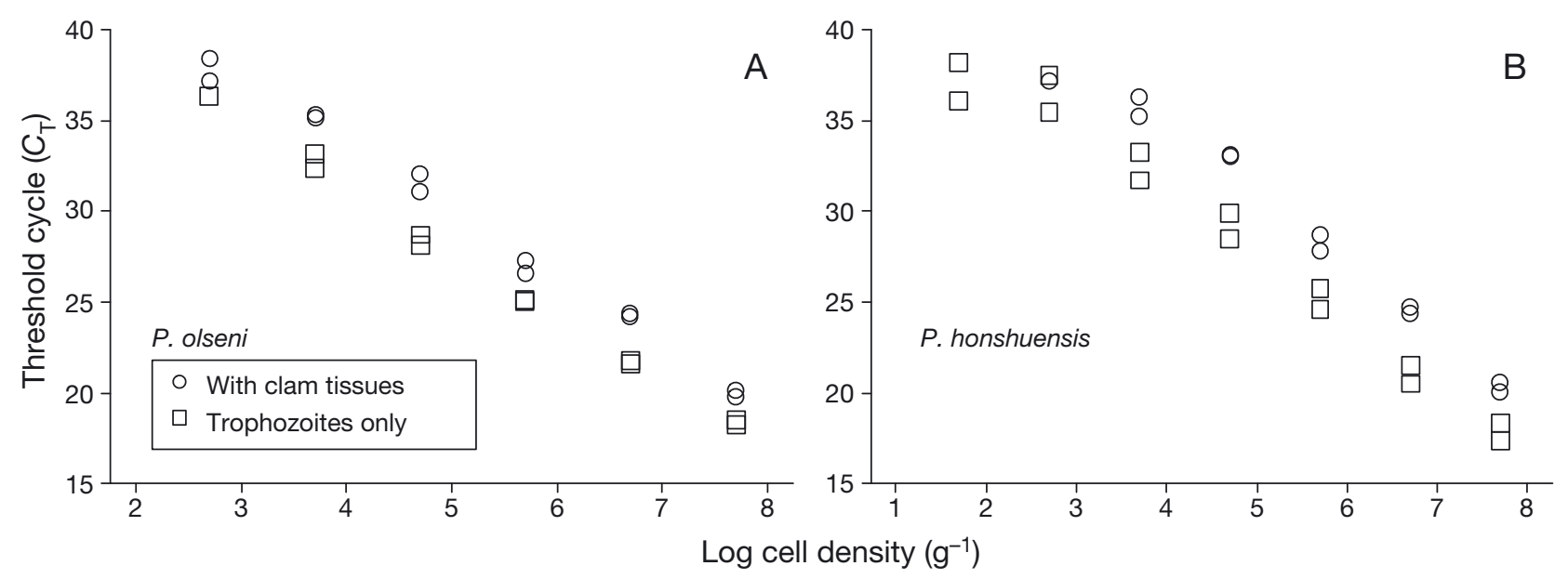

Fig. 1. Comparison of threshold cycle $\left(C_{\mathrm{T}}\right)$ values between DNA solutions extracted from trophozoites only and clam gill tissues spiked with trophozoites in (A) Perkinsus olseni and (B) P. honshuensis

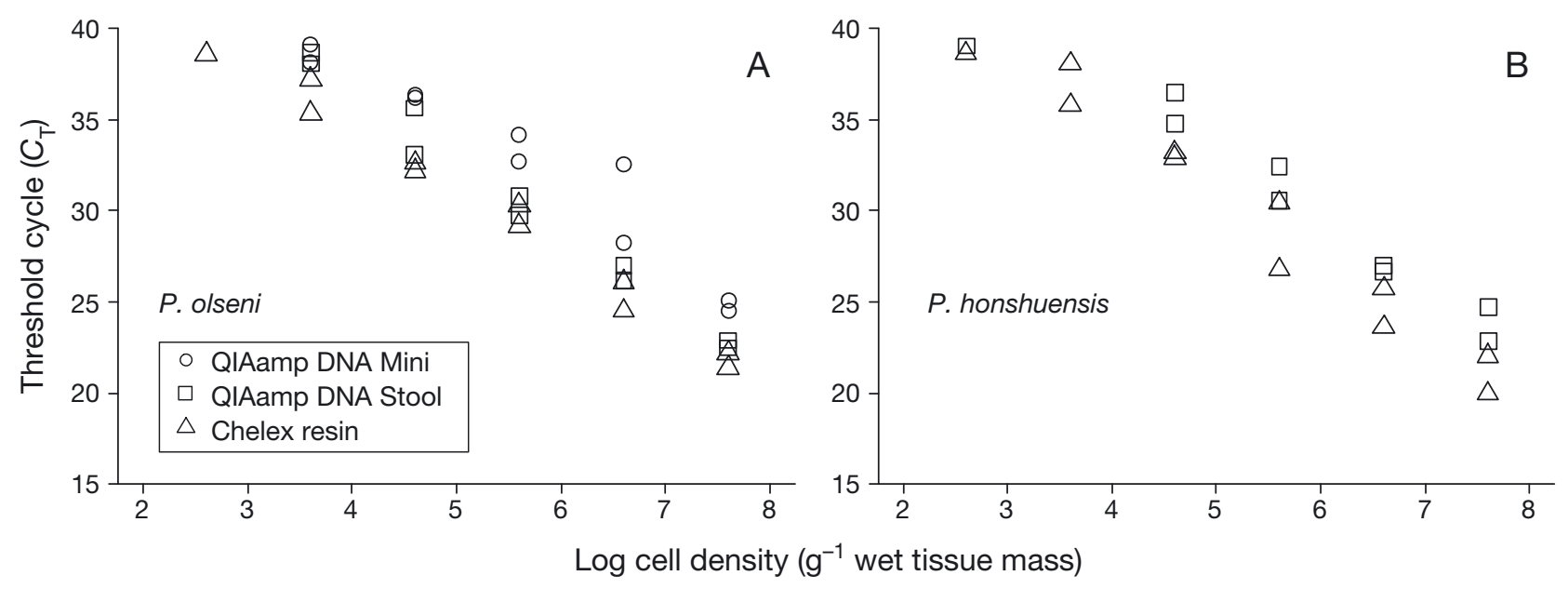

Fig. 2. Comparison of threshold cycle $\left(C_{\mathrm{T}}\right)$ values for DNA extracted using one of 3 methods from clam gill tissue spiked with trophozoites of (A) Perkinsus olseni and (B) P. honshuensis

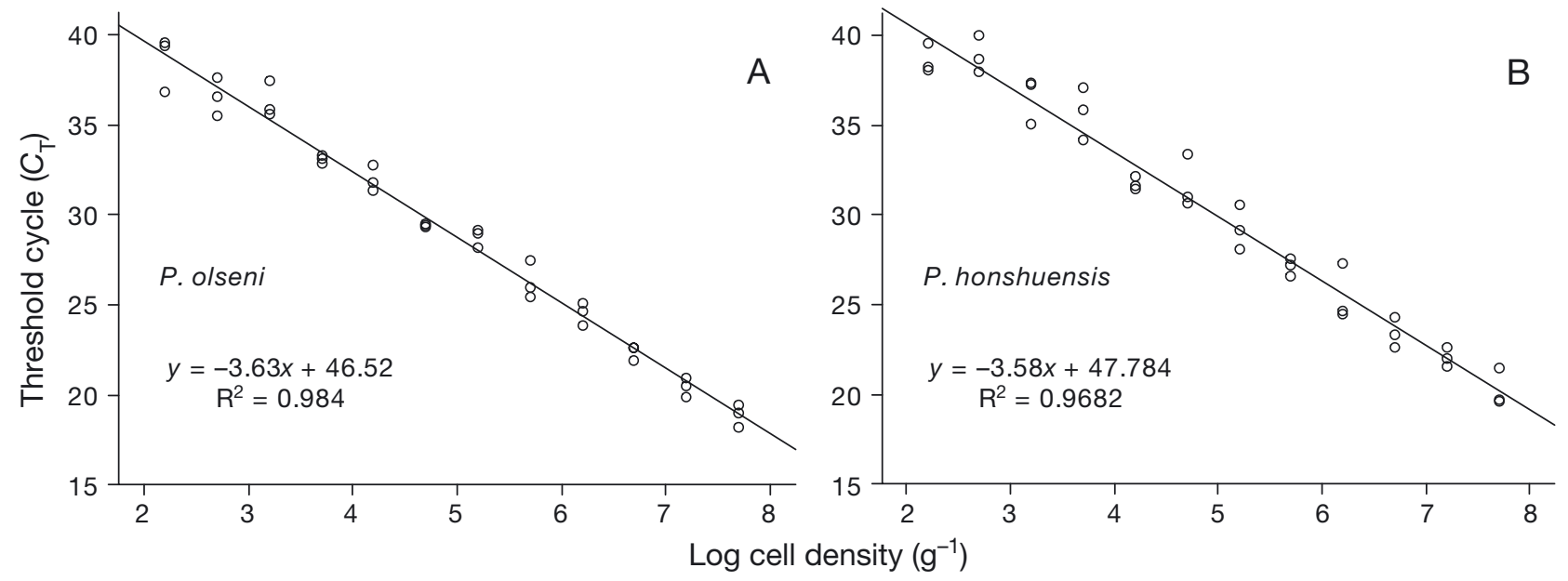

Fig. 3. Standard curve representing the relationship between cell density (cells $\mathrm{g}^{-1}$ wet gill) and threshold cycle ( $C_{\mathrm{T}}$ ) values of real-time PCR of (A) Perkinsus olseni and (B) P. honshuensis 


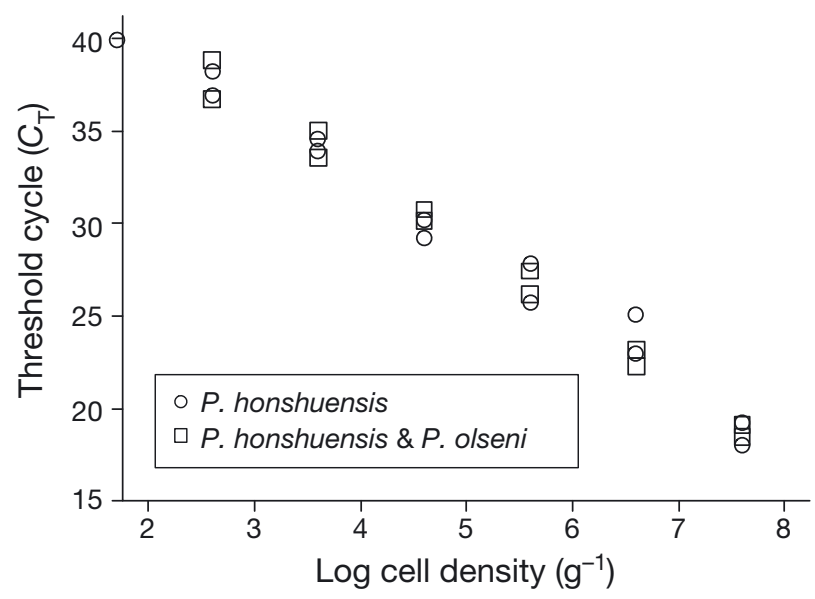

Fig. 4. Threshold cycle $\left(C_{\mathrm{T}}\right)$ values for DNA extracted from clam gill tissues spiked with Perkinsus honshuensis only and tissues spiked with both P. honshuensis and P. olseni

\section{Comparison of preservation method and tissue type}

The method of tissue preservation had little effect on the $C_{\mathrm{T}}$ value for both Perkinsus species (Fig. 5). Similarly, there was little difference between standard samples prepared with gill tissue or whole body tissue for both Perkinsus species (Fig. 6).

\section{Comparison of real-time PCR and RFTM assays}

All of the 92 Manila clams we examined were positive in the RFTM assay. Conversely, 64 clams were positive only for Perkinsus olseni, 2 were positive for only $P$. honshuensis, 13 were positive for both $P$. olseni and $P$. honshuensis, and 13 were negative for

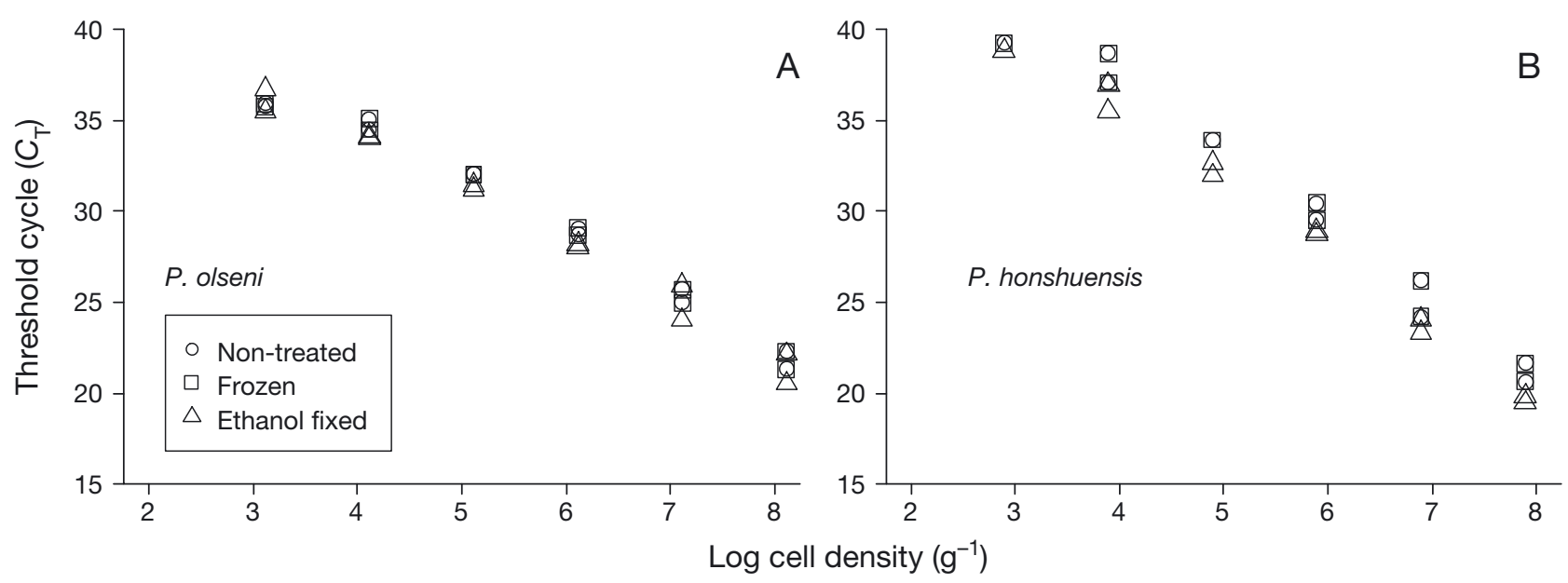

Fig. 5. Comparison of threshold cycle $\left(C_{\mathrm{T}}\right)$ values of cell density ( $\mathrm{g}^{-1}$ wet gill) of (A) Perkinsus olseni and (B) P. honshuensis extracted from gills that were preserved using one of 3 methods: non-treated, frozen, and ethanol fixed

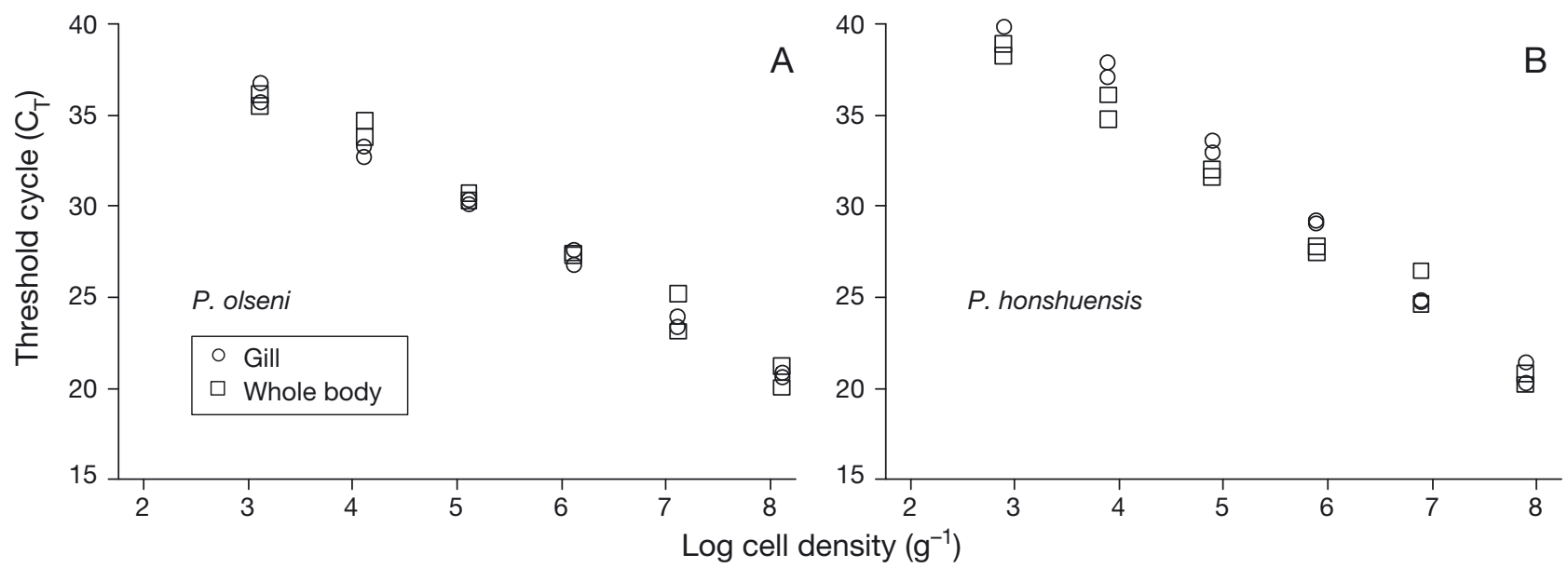

Fig. 6. Threshold cycle $\left(C_{\mathrm{T}}\right)$ values of cell density ( $\mathrm{g}^{-1}$ wet gill) of (A) Perkinsus olseni and (B) P. honshuensis extracted from the gill or whole body 
both $P$. olseni and $P$. honshuensis in the real-time PCR assays (Table 4). The prevalence of $P$. olseni was much higher than for $P$. honshuensis at all localities. Similarly, the infection intensity was between 16 and 40000 times higher for $P$. olseni than for $P$. honshuensis in the clams that were positive for both species in real-time PCR (Fig. 7). The infection intensity of $P$. honshuensis $\left(5.6 \times 10^{3}\right.$ cells $\left.^{-1}\right)$ tended to be higher in clams that were collected at the site where $P$. honshuensis was first documented. There was a significant linear correlation between the combined (both species) infection intensity determined by real-time PCR and RFTM $\left(\mathrm{r}^{2}=0.70, \mathrm{p}<0.05\right)$, after removal of PCR-negative clams from the analysis (Fig. 8A). In the Bland-Altman plot, the differences between the infection intensities determined by the 2 methods were independent of the infection intensity $\left(\mathrm{r}^{2}=\right.$ 0.0136, p > 0.05). Furthermore, the mean log intensity obtained using real-time PCR was significantly higher $(0.15)$ than that obtained using RFTM (paired t-test, $\mathrm{p}<0.05$; Fig. 8B).

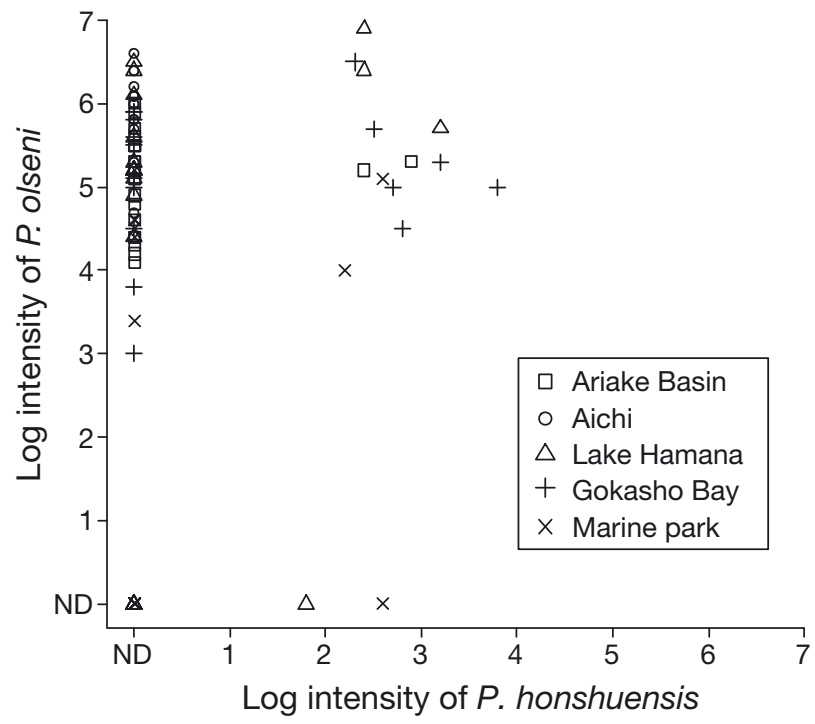

Fig. 7. Infection intensity of Perkinsus olseni and P. honshuensis in Manila clams from various locations measured by real-time PCR. Each symbol represents the value for an individual clam. ND: not detected

\section{DISCUSSION}

In general, studies of infectious diseases require methods for the identification and quantification of pathogens. Two species of the genus Perkinsus ( $P$. olseni and $P$. honshuensis) have been found in Manila clams in Japan, often co-infecting single clams (Dungan \& Reece 2006, Takahashi et al. 2009). These 2 species cannot be distinguished morphologically (Dungan \& Reece 2006), thus necessitating the development of methods for their discrimination and quantification. Takahashi et al. (2009) developed a PCRRFLP method that could be used to discriminate the 2 species and document their presence, but not for quantification. To our knowledge, the present study is the first report of real-time PCR methods for discriminatory quantification of $P$. olseni and $P$. honshuensis.

We distinguished the 2 species using primer sets that targeted sequences unique to $P$. olseni or $P$. honshuensis in the ITS regions either side of the 5.8S ribosomal DNA region. Interestingly, the primer set OF/OR, designed for P. olseni, also amplified P. honshuensis PRA-176. However, the $C_{\mathrm{T}}$ values differed considerably between the primer sets (15.7 and 26.7 for $\mathrm{HF} / \mathrm{HR}$ and $\mathrm{OF} / \mathrm{OR}$, respectively). Assuming that the amplification efficiency for both primer sets was 2.0, we estimate that strain PRA-176 contains 2000fold more $P$. honshuensis than $P$. olseni. P. honshuensis PRA-176 is a polyclonal strain from which the monoclonal strain $P$. honshuensis PRA-177 was derived. Given that $P$. honshuensis PRA-177 was not amplified using the OF/OR primer set, we conclude that $P$. honshuensis PRA-176 was contaminated with a small number of $P$. olseni cells.

Clam tissues contain compounds that often inhibit PCR reactions (Nakatsugawa 2007). Thus, it is important to optimize DNA extraction for PCR to reduce the inhibitory effect. We tested 3 extraction methods and found that $10 \%$ Chelex resin solution was the most effective at minimizing the inhibitory effect on real-time PCR. However, DNA samples extracted from clam gill tissues spiked with trophozoites

Table 4. Infection intensity (cells $\mathrm{g}^{-1}$ wet gill) of Perkinsus olseni and P. honshuensis at each site, measured by real-time PCR

\begin{tabular}{|c|c|c|c|c|c|c|c|}
\hline \multirow[t]{3}{*}{ Site } & \multirow{3}{*}{$\begin{array}{c}\text { No. clams } \\
\text { tested }\end{array}$} & \multicolumn{3}{|c|}{ P. olseni } & \multicolumn{3}{|c|}{ P. honshuensis } \\
\hline & & \multirow[t]{2}{*}{ No. infected clams } & \multicolumn{2}{|c|}{ Infection intensity } & \multirow[t]{2}{*}{ No. infected clams } & \multicolumn{2}{|c|}{ Infection intensity } \\
\hline & & & Min. & Max. & & Min. & Max. \\
\hline Ariake Basin & 22 & 22 & $1.3 \times 10^{4}$ & $9.5 \times 10^{5}$ & 2 & $2.8 \times 10^{2}$ & $7.8 \times 10^{2}$ \\
\hline Aichi Prefecture & 16 & 16 & $5.4 \times 10^{4}$ & $3.6 \times 10^{6}$ & 0 & 0 & \\
\hline Lake Hamana & 18 & 14 & $2.6 \times 10^{4}$ & $7.9 \times 10^{6}$ & 3 & $2.3 \times 10^{2}$ & $1.7 \times 10^{3}$ \\
\hline Mie Prefecture & 16 & 16 & $9.5 \times 10^{2}$ & $2.9 \times 10^{6}$ & 6 & $1.9 \times 10^{2}$ & $5.6 \times 10^{3}$ \\
\hline Marine Park & 20 & 9 & $2.4 \times 10^{3}$ & $1.6 \times 10^{5}$ & 3 & $1.2 \times 10^{2}$ & $4.3 \times 10^{2}$ \\
\hline
\end{tabular}



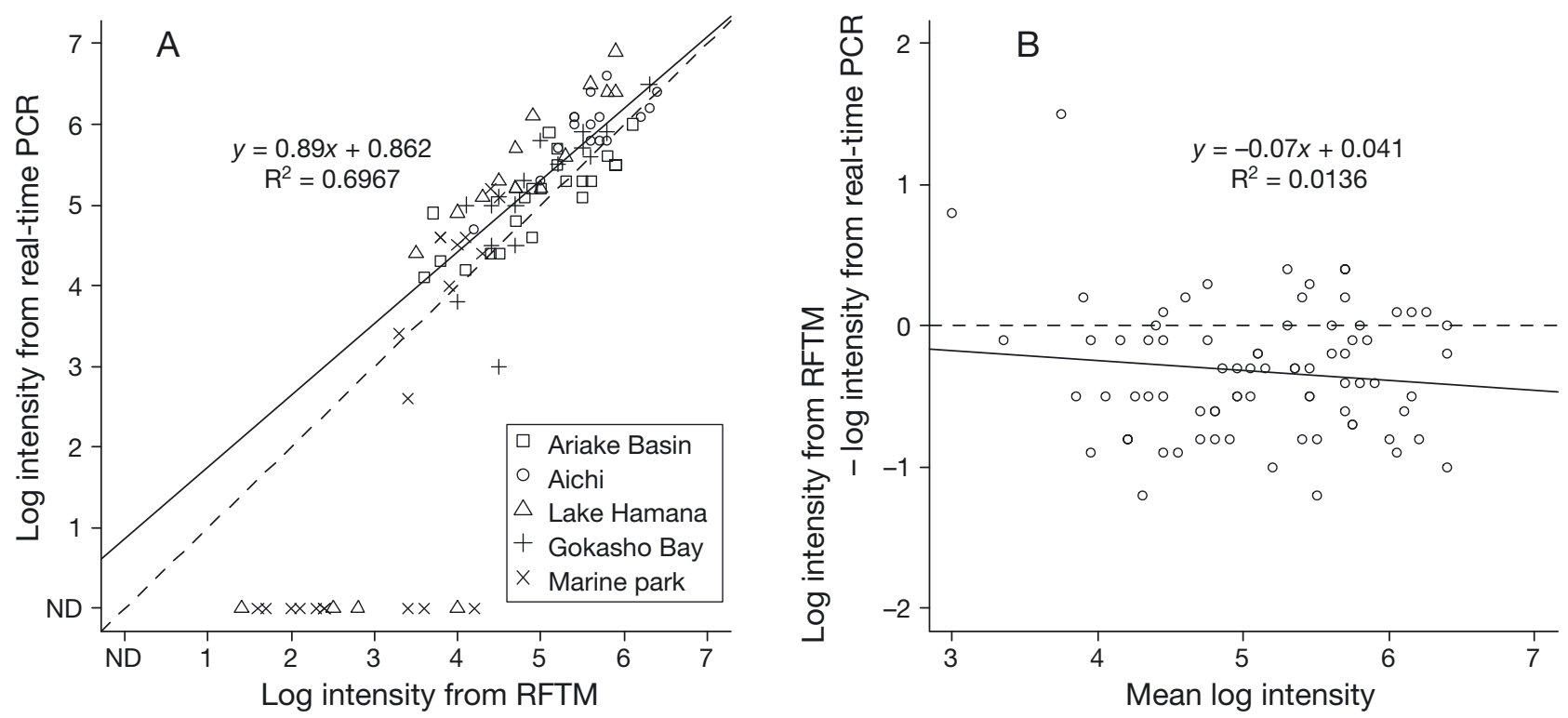

Fig. 8. (A) Relationship between the combined infection intensity (cells $\mathrm{g}^{-1}$ wet gill) of Perkinsus olseni and $P$. honshuensis determined by Ray's Fluid Thioglycollate Medium (RFTM) assay and by real-time PCR. The solid and dashed lines represent the correlation between the 2 intensities and the line $x=y$, respectively. ND: not detected. (B) Bland-Altman plot of the intensities determined by the 2 methods. The difference in log intensity obtained by the 2 methods was plotted against the mean log intensity obtained by the 2 methods. The solid and dashed lines represent the correlation between the difference and mean intensity and the line $y=0$, respectively

yielded higher $C_{\mathrm{T}}$ values than those extracted from trophozoites only. Therefore, we used DNA extracted from gill tissue spiked with a known amount of Perkinsus trophozoites as standards for the real-time PCR assays.

Although spin-column methods have been used frequently to extract DNA from bivalves, we were unable to amplify DNA from samples extracted using the QIAamp DNA Mini kit, which uses spin-column methodology. The OIE manual (World Organization for Animal Health 2010) recommends the use of spincolumn methodology for genus-specific PCR detection of Perkinsus species using the genus-specific primer set (PerkITS-85/PerkITS-750). Given this, we performed real-time PCR using the genus-specific primer sets on samples extracted with the QIAamp DNA Mini kit and Chelex resin. Samples extracted with the QIAamp DNA Mini kit were also successfully amplified, though the $C_{\mathrm{T}}$ values were higher by 2.1 to 4.3 units than those for DNA extracted with Chelex resin (data not shown). The PCR primers and conditions, which differ from those for genus-specific conventional PCR, and the presence of inhibitory chemicals that were not removed by the QIAamp DNA Mini kit may explain the failure to amplify DNA that was extracted using this method. The QIAamp DNA Stool kit also uses an absorption resin, InhibitEx tablet, to remove PCR inhibitors. Given that Chelex resin and the QIAamp DNA Stool kit showed higher efficiency of DNA amplification than the QIAamp DNA Mini kit, the PCR inhibitor in clam tissue may be substance(s) absorbed onto resin, e.g. some kind of metallic ion. In this study, we adopted Chelex resin as a standard method because of the efficiency of PCR amplification and the simplicity of the protocol.

The PCR reaction yielded a linear standard curve using DNA extracted from clam gill tissues spiked with known numbers of trophozoites, suggesting that the assay may be used for the quantification of both Perkinsus olseni and P. honshuensis. Furthermore, the assay was able to successfully quantify the infection intensity of $P$. honshuensis in the presence of $P$. olseni trophozoites.

DNA amplification was detected within the range of $5.0 \times 10^{7}$ to $5.0 \times 10^{1.5}$ trophozoites $\mathrm{g}^{-1}$ wet gill tissue for both Perkinsus olseni and P. honshuensis. In wild Manila clams, the highest infection intensity of Perkinsus species is generally approximately $10^{7}$ cells g ${ }^{-1}$ wet gill tissue (Choi et al. 2002, Park et al. 2008, Yoshinaga et al. 2010), which is within the range that can be quantified using our method. Takahashi et al. (2009) showed that the lower limit of detection by PCR-RFLP was 100 cells per $10 \mathrm{mg}$ tissues (10000 cells $\mathrm{g}^{-1}$ tissue) for P. olseni and one cell (100 cells $\mathrm{g}^{-1}$ tissue) for $P$. honshuensis. Therefore, both assays are comparable in sensitivity.

There was little difference in the quantification of infection intensity by real-time PCR between the 
frozen, ethanol-fixed, and fresh standard samples spiked with Perkinsus trophozoites. Moreover, we found no difference in the sensitivity of the assays between samples of gill tissue and whole body. Thus, our results suggest that both frozen and ethanolfixed samples of the gill or whole body can be used to quantify infection intensity using these real-time PCR assays.

There was a linear correlation of the infection intensity of wild Manila clam samples between the realtime PCR and RFTM assays. However, the values obtained by real-time PCR were higher than those obtained by RFTM. This difference may be explained in 2 ways: (1) some existing Perkinsus trophozoites did not mature into hypnospores in the RFTM assay or (2) the DNA of dead cells is amplified by PCR.

Although the detection efficiency was high for the real-time PCR assays, some samples that tested positive in the RFTM assay were negative in the realtime PCR assays, particularly for clams with low infection intensities. Assuming all the trophozoites are enlarged in RFTM, the assay is able to detect the presence of even a single cell. Conversely, DNA is only extracted from a fragment of the tissue $(<40 \mathrm{mg})$ prior to real-time PCR. Because Perkinsus spp. cells tend to be unevenly distributed in Manila clam tissues, the lack of amplification may be attributable to the low volume of tissue used for DNA extraction. Thus, an increase in the lower threshold of detection by real-time PCR likely requires an increase in sample volume. These real-time PCR assays are well suited for field research but less suited for diagnostic purposes. The level of infection with $P$. honsehuensis was much lower than that of $P$. olseni at all the locations examined in this study, consistent with the observations of Takahashi et al. (2009). P. olseni is likely predominant in the Manila clam populations examined in this study. Interestingly though, the infection intensity of $P$. honshuensis tended to be higher in clams that were collected from the site at which this species was first described, perhaps explaining why Dungan \& Reece (2006) were able to isolate $P$. honshuensis in their earlier study.

The PCR primer set for Perkinsus honshuensis was designed based on the DNA sequence of a clonal isolate from only one locality. In addition, we have not checked the specificities of the primers we developed in this study for $P$. olseni and $P$. honshuensis against $P$. beihaiensis, as a cultured strain of $P$. beihaiensis is currently available. The specificities and efficacies of the primers may need to be tested when additional cultures of $P$. honshuensis and $P$. beihaiensis become available.
Acknowledgements. We thank Mr. M. Soejima (Bio-Rad Laboratories Japan, Tokyo) for technical assistance during real-time PCR development. We also thank Mr. Chris Dungan, Cooperative Oxford Laboratory, Maryland Department of Natural Resources, for providing us with alcohol-fixed specimens of various Perkinsus species. Our thanks also go to Ms. Y. Jo and Mr. M. Fujita at the Fisheries Laboratory, Graduate School of Agricultural and Life Sciences, The University of Tokyo, and students in our laboratory for their help in the collection of Manila clams. This study was supported by KAKENHI (Grant-in-Aid for Scientific Research (B), 22380106) by the Japan Society for the Promotion of Science (JSPS).

\section{LITERATURE CITED}

Andrews JD, Hewatt WG (1957) Oyster mortality studies in Virginia. II. The fungus disease caused by Dermocystidium marinum on oysters of Chesapeake Bay. Ecol Monogr 27:1-25

Azevedo C (1989) Fine structure of Perkinsus atlanticus n. sp. (Apicomplexa, Perkinsea) parasite of the clam Ruditapes decussatus from Portugal. J Parasitol 75:627-635

Barber PH, Erdmann MV (2000) Molecular systematics of the Gonodactylidae (Stomatopoda) using mitochondrial cytochrome oxidase $C$ (subunit 1) DNA sequence data. J Crustac Biol 20:20-36

Casas SM, Villalba A, Reece KS (2002) Study of perkinsosis in the carpet shell clam Tapes decussatus in Galicia (NW Spain). I. Identification of the etiological agent and in vitro modulation of zoosporulation by temperature and salinity. Dis Aquat Org 50:51-65

Choi KS, Wilson EA, Lewis DH, Powell EN, Ray SM (1989) The energetic cost of Perkinsus marinus parasitism in oysters: quantification of the thioglycollate method. J Shellfish Res 8:125-131

Choi KS, Park KI, Lee KW, Matsuoka K (2002) Infection intensity, prevalence, and histopathology of Perkinsus sp. in the Manila clam, Ruditapes philippinarum, in Isahaya Bay, Japan. J Shellfish Res 21:119-125

Cremonte F, Balseiro P, Figueras A (2005) Occurrence of Perkinsus olseni (Protozoa: Apicomplexa) and other parasites in the venerid commercial clam Pitar rostrata from Uruguay, southwestern Atlantic coast. Dis Aquat Org 64: 85-90

> De Faveri J, Smolowitz RM, Roberts SB (2009) Development and validation of a quantitative PCR assay for the detection and quantification of Perkinsus marinus in the eastern oyster, Crassostrea virginica. J Shellfish Res 28: 459-464

Dungan CF, Reece KS (2006) In vitro propagation of two Perkinsus spp. parasites from Japanese Manila clams Venerupis philippinarum and description of Perkinsus honshuensis n. sp. J Eukaryot Microbiol 53:316-326

Ewart JW, Ford SE (1993). History and impact of MSX and dermo diseases on oyster stocks in the northeast region. NRAC Fact sheet No. 200, Northeastern Regional Aquaculture Center, University of Massachusetts, Dartmouth, MA

> Goggin CL, Lester RJG (1995) Perkinsus, a protistan parasite of abalone in Australia: a review. Aust J Mar Freshw Res 46:639-646

> Hamaguchi M, Suzuki N, Usuki H, Ishioka H (1998) Perkinsus protozoan infection in short-necked clam Tapes 
(=Ruditapes) philippinarum in Japan. Fish Pathol 33: 473-480

Hamaguchi M, Sasaki M, Usuki H (2002) Prevalence of a Perkinsus protozoan in the clam Ruditapes philippinarum in Japan. Jpn J Benthol 57:168-176

Matsukawa Y, Cho N, Katayama S, Kamio K (2008) Factors responsible for the drastic catch decline of the Manila clam Ruditapes philippinarum in Japan. Bull Jpn Soc Sci Fish 74:137-143

Nakatsugawa T (2007) Improvement of a PCR detection method for Perkinsus olseni isolated from Manila clam, Ruditapes philippinarum. Bull Kyoto Inst Ocean Fish Sci 29:17-21

Nishihara Y (2010) Infection of protozoan Perkinsus in the short-necked clam (Ruditapes philippinarum) on the Hokkaido coastal region and the infection examination. Sci Rep Hokkaido Fish Exp Stn 77:83-88

Park KI, Choi KS (2001) Spatial distribution of the protozoan parasite Perkinsus sp. found in Manila clams, Ruditapes philippinarum, in Korea. Aquaculture 203:9-22

Park KI, Tsutsumi H, Hong JS, Choi KS (2008) Pathology survey of the short-neck clam Ruditapes philippinarum occurring on sandy tidal flats along the coast of Ariake Bay, Kyushu, Japan. J Invertebr Pathol 99:212-219

Ray SM (1952) A culture technique for the diagnosis of infection with Dermocystidium marinum Mackin, Owen and Collier in oysters. Science 116:360-361

Ray SM (1966) A review of the culture method for de-

Editorial responsibility: Eugene Burreson,

Gloucester Point, Virginia, USA tecting Dermocystidium marinum, with suggested modifications and precautions. Proc Natl Shellfish Assoc 54: 55-69

Ruano F, Cachola R (1986) Outbreak of a severe epizootic of Perkinsus marinus (Levin-78) at Ria de Faro clam's culture beds. Proc 2nd Int Colloq Pathol Mar Aquac (PAMAQ II), Oporto, Portugal, p 41-42

Saldarriaga JF, McEwan ML, Fast NM, Taylor FJR, Keeling PJ (2003) Multiple protein phylogenies show that Oxyrrhis marina and Perkinsus marinus are early branches of the dinoflagellate lineage. Int J Syst Evol Microbiol 53:355-365

Takahashi M, Yoshinaga T, Waki T, Shimokawa J, Ogawa K (2009) Development of a PCR-RFLP Method for differentiation of Perkinsus olseni and $P$. honshuensis in the Manila clam Ruditapes philippinarum. Fish Pathol 44: 185-188

Villalba A, Reece KS, Ordas MC, Casas SM, Figueras A (2004) Perkinsosis in molluscs: a review. Aquat Living Resour 17:411-432

World Organization for Animal Health (2010) Infection with Perkinsus olseni. In: Aquatic animal health code. OIE, Paris, Available at: www.oie.int/index.php?id $=171 \& \mathrm{~L}=0$ \&htmfile=chapitre_1.11.6.htm

> Yoshinaga T, Watanabe S, Waki T, Aoki S, Ogawa K (2010) Influence of Perkinsus infection on the physiology and behavior of adult clam Ruditapes phillipinarum. Fish Pathol 45:151-157

Submitted: August 17, 2011; Accepted: April 3, 2012 Proofs received from author(s): July 10, 2012 